\title{
Training Management Effectiveness
}

\author{
Erna Kusumawati \\ STMIK Nusa Mandiri Jakarta \\ ernakusumawati19@gmail.com
}

\begin{abstract}
This study examine the effectiveness of training management in privat higher education. This studi aim to is a means to develop the competence of lecturers in terms of skills, knowledge and attitudes. The study evaluated the effectiveness of management training in Nusa Mandiri STMIK Jakarta, STMIK Nusa Mandiri Sukabumi and STIBA Nusa Mandiri Ciputat. This study aim to describe the planning, need assesment analysis, implementation, evaluating and impact of training in three college, analyze the effectiveness of planning, implementation, evaluating and impact of the training lecturer at three privat college an at the end to formulate hypothetical model for the effective training of lecturers Colleges especially in STMIK Nusa Mandiri Jakarta, STMIK Nusa Mandiri Sukabumi and STIBA Nusa Mandiri Ciputat. The research method uses descriptive qualitative approach with case studies. Selection of data sources using purposive sampling and snowball technique. Data collection using in-depth interviews, observation and documentation study. Informant interviews consisted of the faculty leaders, lecturers and students. Analysis of data by data reduction, data display and data verification. The need to create a system of quality assurance for the facilitator, participants, facilities and training methods. Availability of resources and management commitment to support the implementation of quality assurance management training.
\end{abstract}

Keywords- Effectiveness, Planning, Implementation, Assessment, Impact Training

\section{INTRODUCTION}

College supposedly able to optimize the community needs both to science, technology mastery as well as to meet the needs of experts in various fields. The global and local Dialectics is very prominent in the debate contemporary social science and have a significant impact on higher education studies. [1] The implications of the study of education is the development of higher Education institutions that have quality. In the global era demands both quality and competition among universities, especially private is a common phenomenon. Colleges and universities, faced with the challenges of the new knowledge-based global society, must reinvent themselves and rethink their roles and purposes. Lecturers are required to understand the professional duties. Teaching and learning are two dimensions of the academic world and both depend on lecturers capabilities therefore, an effective lecturer has been conceptualized as one who produces desired outcomes in the course of his duty as a lecturer.[2]

Professionalism lecturer realized because of the factors that influence it, such as the factor of knowledge, skills and psychological. [3] Professionalism lecturers need to be supported by a wide range of expertise and skills. Knowledge and skills can be acquired through various types of training. Training is a series of activities that provide an opportunity for faculty to gain and improve skills related to their duties in implementing the Tri Dharma College.

The training aims to increase the capacity of human resources in order to become qualified resources both in terms of knowledge, skills, high level of professionalism in the work in order to improve the ability to achieve the expected goals.

Gap between the training has been done by the three campuses under Indonesia Nusa Mandiri Foundation and standardized training should lead to the need for a study on the effectiveness of the training was good. The effectiveness of training seen from the effectiveness of planning, implementation, and impact assessment for the progress position of individual and institutions. The purpose of the training is expected to renew expertise faculty lecturer in line with changes in technology, help solve problems, especially in teaching and learning in the classroom and improve the professionalism of lecturers in accordance duties as educators, researchers and the public servants.

Training is very important for human resources to work more and better control of the job held or to be held next in an effort to improve the performance of labor education is deemed not able to carry out its work because of the development community needs dalarn education. In particular description of potential workers may have already qualified education administration of the job, but the actual education workers must follow or balance the development of education in accordance with the tasks to be occupied or will he held. It is encouraging the education offices to facilitate training and career development of labor education in order to get a good performance results, effectively and efficiently.

One of the functions of human resource management is training and development. Educational resources (faculty) need training. Lecturer become one of the key factors in the implementation and development of higher education, there are three major functions of the college called the tri dharma college, namely: 1) education and learning, 2) Research and 3) community service. In the third dharma lecturers were the main perpetrators. Lecturers are required as planners, implementers, controllers and evaluators of learning process (lectures). Dharma study conducted lecturers to deepen and improve their knowledge and apply mastery. Dharma devotion made a lecturer in the framework of the application of knowledge and skills possessed as to foster community development.

Based on some information from the study of literature it is known that there are 98 types of training that has been organized by the Training section from 2009 to 2014 respectively distinguished research-based material. Materials provided grouped into the field of computer science, English, learning, graphic design and public. 
From these data it is known that from the side of the material is sufficient to provide additional knowledge and skills of lecturers, but if terms of the number of participants so far the range is from 11 to 200 lecturers. This gives the impression that the training is done not based on the analysis of the needs of lecturers. During this training undertaken lecturers are more operating systems that are not placing lecturers function optimally. Training is based on the lack of conformity lecturer functions as educators, researchers and public servants in higher education (organization). Training not contributed the maximum because it is held with less thorough needs analysis. Training does not encourage the participants and organizations to put the principle of lifelong learning. Management training administration lecturer at the three campuses is not yet a system designed in a systematic and planned start of the initial activities include needs assessment (individual level by level organizations), as well as measuring the impact of training activities at the organizational level.

The training has been carried out on all three campuses Indonesia Nusa Mandiri Foundation are still many gaps and inaccuracies with management training should be and standardized. The number of training does not guarantee improved lecture performance. Many professors who teach by lecture method, do not do aperseption before attending to the matter and does not provide pre-test to the student. Organizing commitee did not report the results of the training which has been produced from the implementation. Ttraining impact is not apparent, especially on the organization's objectives.

In practice, only a small portion of training institutes conducting the assessment in detail with the assessment of conformity with the level by using analytical tools appropriate. STMIK organizers in Jakarta, Sukabumi and Ciputat just analyzing the effectiveness of training is apparent to the training provided. Institutions not using the test pre test post test or test of effectiveness at the organizational level by using the right tools. In addition the analysis of training needs has not been using tools appropriate analyzes such as interviews, observation, job description, questionnaires, tests, case studies, working diagnosis sheet.

The ability of lecturers will affect how the intake for students in the future related to its capacity.[4] Improving the quality of lecturers from year to year shows the quality of the institution. Legislation national education system No. 20 of 2003 Article 20 requires that the main task of a teacher is doing Tri Dharma College, namely education and teaching, research and community service.

Training for professors and their application in academic activities affect the quality of their teaching and learning. [5] Training is an attempt to develop the knowledge (knowledge), abilities (ability), expertise (skills) and attitude (attitude) individual in performing the tasks for the increasing performance. The aim of training program are: 1 . to do to close the "gap" between the skill and ability of faculty to demand positions. 2. The programs are expected to improve the efficiency and effectiveness of the faculty in achieving work goals expected. These training efforts initially time consuming and costly, but after returning to work would save costs.
Training avoid wastage of time and money because the lecturers are able to work effectively and efficiently so that the performance increasingly. Training is completed can improve the mastery of various skills and techniques specific work practices, and procedures that apply in the company.

Results of research on some of the criteria for evaluating the effectiveness of a training that reaction, learning, behavior and goals of the organization work showed that the training organized in some places they are not supported by training evaluation. The results were analyzed using the only description training apparent by observation of the behavior of the lecturers at the workplace with the assumption that the training will prove itself without measurements.[5] Evaluation is probably the most important part of the training system; without it, one cannot see whether the investment in human capital is producing the right kind of return. Arguably, this step is also the most challenging part of the training process". [6]

The difference of this study with previous research is of different viewpoints. This study seeks to express views based on the philosophy of education administration to training as a system that has the goal oriented, holistic and forward the scientific process. Incompatibility reality about the effectiveness of training with interpretation researchers with a systematic research effort to produce a more thorough description of reality can be minimalized. The views research analysis is based on a training position as human resource development activities as a strategic partner not just an administrative agency expert.

The results of the study attempts to untangle the reality gap between expectations with reality based on the changes that have dialectical discourse with the social practice of training within the framework of the science of educational administration. The results of the dialectic of "problem solving" the problem of training both theoretically and practically on a regular basis, be resolved through cooperation between individual and organizational structure. [7], [8]. [9], [10], [11], [12].

\section{METHOD}

Qualitative research with the approach chosen as the case study method. Research sites in Indonesia Nusa Mandiri Foundation campus consisting of the campus area Kopertis III and IV. Location of the research conducted at the campus of Yayasan Indonesia Nusa Mandiri. Subjects were sampled lecturers who were in STMIK Nusa Mandiri Jakarta, STMIK Nusa Mandiri Nusa Mandiri STIBA Sukabumi and Tangerang Ciputat. Estimated time to research conducted for about 1 year at the start of August, 2014 to August, 2015.

Data collection techniques as a tool for research instrument used in this study include: in-depth interviews, observation and documentation. Researchers went to the field to collect data based on the previously developed category. The data obtained through interviews, observation and documentation stored in a tape recorder, video, field notes and then processed.

The data consists of data reduction, data display, and data analysis. Increasing the validity of the research results through cross-examination on the research procedure that has been performed as well as a review of 
the substance of the research, by testing the credibility, transferability, dependability and conformability.

Credibility can be increased by multiplying the involvement of researchers in the field this has been carried out throughout 2014 to 2015, continuous observation conducted on the aspect of infrastructure and ongoing training activities. Triangulation of data used for the data to be checked through different data collected from some people, carried out in different times and places. Transferability increased if the results can be applied by users of research. Dependability and conformability can be done through an audit trail and communication with mentors and experts in the field of science research that has been done when the counseling process.

Data validation is very important that the analysis of the data can be justified scientifically. [14] In this study, a measure for validation are as follows: 1 . extend the participation of researchers in the process of data collection in the field, 2. observation constantly and earnestly to the problems that are the focus of research and 3. triangulate. The research data obtained through the research questions that had been predetermined, including planning, implementation, evaluation and implementation of training result. Data used in this study are primary and secondary data. Primary data was obtained in the form of words and attitudes sources (informants) from the interview relating to the organization of training. The data obtained in this study derived from human (informant), and physical documents. Sources of data from humans is a source of key informants and supporters. Based on the research objectives of human resources as an informant is: 1. Elements of the leadership responsible for training policy (Chairman, Chairman LPPM, Head of Human Resources); 2. Elements organizer; 3. Lecturer as a trainee; 4. Direct superior lecturer (chairman of the program).

Data analysis procedures in general in this study conducted with the following steps: data reduction, data display, validation, and verification of data conclusions. Researchers in conducting data analysis adhering to the principle of qualitative data analysis, namely data shown is not a series of numbers but a series of words that do repetitive, ongoing and continuous until the analysis is considered sufficient. Data analysis was performed in interactive activities. Data analysis in qualitative research conducted since before entering the field, on the field during and after its completion in the field.

\section{RESULT AND DISCUSSION}

This research describe training management stages in STMIK Nusa Mandiri Jakarta, STMIK Nusa Mandiri Sukabumi and STIBA Nusa Mandiri Ciputat. Analyze the effectiveness of training management in STMIK Nusa Mandiri Jakarta, STMIK Nusa Mandiri Sukabumi and STIBA Nusa Mandiri Ciputat can proveble. There is a hypothetical model for the effective training of lecturers Colleges especially in STMIK Nusa Mandiri Jakarta, STMIK Nusa Mandiri Sukabumi and STIBA Nusa Mandiri Ciputat be formulated in this research. The findings of the study states that there are differences of these three private universities.
At the planning stage in STMIK Nusa Mandiri Jakarta, TNA has not been carried out based on the needs at the organizational level explicitly. TNA is false. TNA on a limited description, there is no early test participants and support for requirements analysis is weak. Coverage of training focused on work currently faced by the lecturers. The purpose of training - goal oriented to meet most of the needs of the participants, the tasks and the organization's needs against the availability of lecturers who can run optimally college tri dharma. Most of the curriculum has been adapted to the needs of participants and institutions. There is a continuity of the material in accordance with the implementation of the functional tasks of lecturers. The curriculum in accordance with the current faculty task. Learning time is not optimal for utilizing the working hours. Facilities and facilitators come from the campus to the selection of participants based on the consideration of the leadership.

The implementation obtained from research are preparation of adequate teaching by experienced facilitators though there are several facilitators inexperienced and stiff. The choice of method is not fully in accordance with the wishes and characteristics of the participants. trainees have responded positively although there has been no detailed analysis measurement analysis is only apparent.

Evaluation stage improve that iinstitutions do not conduct tests of knowledge, attitudes or competencies. The Impact of the training there is support the training outcomes of leadership despite the impact of the training has not been entirely appropriate, necessary adjustments.

Planning in STMIK Nusa Mandiri Sukabumi are TNA needs analysis is limited to individual competencies and execution of tasks. There are limitations to the analysis of the implementation of the different methods of analysis is false description as a needs analysis. Focus on the current activities is on teaching. The purpose has been to meet the needs of participants expressed explicit for individual goals, organizationally still implicitly. The curriculum needs to be added to the material in accordance with the dynamic needs of the participants. There is continuity although it needs some improvement. The curriculum tailored to the needs of participants. Learning time is carried out after working hours, adequate but not optimal. No selection of participants and facilitators limited availability in the internal environment.

Implementation of the training in this college are aadequate educational interaction process with practical enrichment and sharing experiences. Facilitator considered able to facilitate the participants to interact with the experience and learning resources. The selection of methods adapted to the conditions and characteristics of adult participants. Training activities assist management in planning the regeneration of the leadership, reduction in the number of employees and increase employee motivation. The training activities of employee performance create an effective and efficient organization. Facilitate training of employees to develop skills within the organization and thus naturally help to increase professionalism, organizational values, power faculty productivity and job security. 
Evaluation stages is pparticipants showed a positive reaction to the training component. There are no details about the measurement of evaluation activities.

The impact of the training, pparticipants were able to improve the competence and awareness of duties as a lecturer. The purpose of training is considered appropriate, but not entirely as expected. There is support for climateneutral, yet fully achievement-oriented. The application of the material is relevant, there needs to be some adjustments. Necessary adjustments and the results of an ongoing program to optimize the role of lecturers for colleges.

Planning of training in STIBA Nusa Mandiri Ciputat are the use of analytical tools limited needs. Focus on the main campus activity in educational services. The design and development of curriculum meets the criteria setting goals based on the needs of the participants but the organization has not fully met. Curriculum update is required according to the needs. There is a continuity of the material as well as some improvements to the curriculum and materials. Learning hours selected in accordance with the conditions of the participants, Held after working hours. Availability of adequate and technical improvements at the time of use. Selection of participants is based on the authority of the leadership.

Implementation of training that the role of a facilitator in the implementation of the common training quite well from their teaching preparation, opening and introduction, mastery of materials, facilitating discussion and concern to participants. Still there are facilitators who are less motivated activity of participants and the enthusiasm on the participants to attract participants.

The evaluation are aassessments of training programs have not been implemented fully. The new first-rate able to do the evaluation, the evaluation of the participants' reactions to the implementation of the training program. Action assessment was limited to the implementation of successful training to absorb the budget. Assessment which aims to assess the extent to which the training goals and objectives as a way for the development of human resources as a strategic partner has not been fully realized. In essence training provider has never asked for or facilitate the trainees to draft a transfer during the training.

The impact of the training is the learning process of training has not fully improve the knowledge, skills and attitudes of lecturers as agents reformer to drive performance improvements include the capability and professionalism in the management of the entire process. There are no media to measure the performance of lecturers formally and objectively lecturer of cause less motivated in doing their job. They do not know whether the work they do is good enough. Bosses do not have a standard that can be used as guidelines to assess the work of lecturers and provide feedback to the lecturer to lecturer performance assessment. The implications of the results of this study are: quality assurance systems necessary to optimize the delivery of training effectiveness training; nnecessary policies that can support the planning, management and assessment training administration; ccommitment to the training required by all parties; renquired working atmosphere achievement-oriented and facilitate the implementation of the results of training on the job by the university.

Recomendation can be given is mmanagement commitment to support the effectiveness of training Development of concepts and practical training on an ongoing basis. For PT who do not have resources and support the implementation of the budget guarantee quality education still needs to be held by way of optimizing the quality function, the role of leader, the participation of all parties, the parents. Organizing committee should carry out planning, requirements analysis, implementation, and assessment. The need for research with a focus that is not much different but still raises novelty. Should need to do further research on the development of the concepts of effective training, internal quality assurance in training lecturers PTS.

\section{REFERENCES}

[1] Brankovic, J et al. Global Challenges, Local Responses in Higher Education. Rhoterdam: Sense Publishers.2014.

[2] Ganieva, Y.,N et.al. Structure and Content of Higher Professional School Lecturer Education Competence. Review of European Studies; Vol. 7, No. 4 hlm 32-38. 2015

[3] Furlong, A. dan Cartmel,F. Higher Education and Social Justice.NY: McGrawHill.2009.

[4] Dora.,M.T., et al. Impacts of Training on Knowledge Dissemination and Application among Academics in Malaysian Institutions of Higher Education. Asian Social Science. Vol. 8, No. 1 hlm 146155.2012

[5] Kealey, Kathleen A.. Arthur V. Peter, Jr. Maria A. Gaul and Khanh T. Dinh. Teaching Training as a Behavior Change Process: Principles amd Results from a Longitudinal Study. Health Education \& Behavior. http"//heb.sagepub.com/content/27/1/64 Oklahoma State University, September 25, 2014.

[6] Skica, T. dan Rodzinka, J. The analysis of training needs In public institutions operating In health care sector in the Podkarpacie province. Financial Internet Quarterly ,e-Finanse”, 8 (1) hlm 85-101.2012.

[7] Shah, H.dan Gopal, Training Needs Analysis for Bus Depot Managers at GSRTC European. Journal of Training and Development. 36 (5) hlm 527-543. 2012.

[8] Kirkpatrick, D. Evaluation Training Program. Second Edition. San Fransisco: Koehler. 1998

[9] Rajasekar, J dan Khan, S. Training and Development Function in Omani Public Sector Organizations: A Critical Evaluation. Journal of Applied Business and Economics vol. 14(2) hlm 3752. 2013.

[10] Khairutdinova, Rezeda R. Review of European Studies; vol. 7, no. 4: 2015 ISSN 1918-7173. E ISSN 1918-7181. Published by Canadian Center of Science and Education. DOI: 10.5539/re.v7n4p77.

[11] Wipassilapa, Sirirat. The Development of an E-training Program for an English Language Training Course under A Collaborative Project between STOU, Thailand and Massey University, New Zealand. International Journal of Arts \& Science 5.3 (2012): 307-315.

[12] Lincoln Yvona, S and Guba, Egon, G. Naturalistic Inquiry. London: Sage Publication.1995.

[13] Satori, Djam'an dan Aan Komariah.(2010). Metodologi Penelitian Kualitatif. Bandung: Alfabeta. 2012. 